\title{
ОСОБЛИВОСТІ ЗАСТОСУВАННЯ НОРМАТИВНИХ ДОКУМЕНТІВ ЩОДО ОБМЕЖЕННЯ ЕМІСІЇ ЗАБРУДНЮЮЧИХ РЕЧОВИН ПРИ СПАЛЮВАННІ БIОМАСИ
}

\author{
М.М. Жовмір ${ }^{1}$, канд. техн. наук, М.О. Будько ${ }^{2}$, канд. техн. наук \\ ${ }^{1}$ Інститут відновлюваної енергетики НАН України \\ 02094 вул. Гната Хоткевича, 20А, м. Київ, Україна \\ ${ }^{2}$ Національний технічний університет України «Київський політехнічний інститут ім. І. Сікорського», \\ 03056 проспект Перемоги, 37, м. Київ, Україна
}

Мета роботи - з'ясування впливу змін у нормативних документах щодо охорони атмосферного повітря від забруднення на подальшу експлуатачію існуючих та впровадження нових енергетичних установок, розробку нових прочесів та котельного обладнання для спалювання біомаси. Представлено аналіз змін чинних міжнародних документів, стандартів та нормативних актів України стосовно обмеження емісії забруднюючих речовин від енергетичних установок зі спалюванням біомаси. Перевиданою директивою СС встановлено екологічні вимоги до великих спалювальних установок (більше 50 МВт) диферениійовані залежно від їх потужності по паливу, що введені для нових установок з 2018р., а для існуючих - впроваджуються у два етапи - 2014 . та 2028р. Нормативними документами України стосовно великих спалювальних установок заплановано поступовий перехід на нормативи СС до 2033р. Зважаючи на особливості введення сучасних екологічних вимог, сумісне спалювання біомаси та вугілля на існуючих великих електричних станціях Украйни може стати реальним 3 наближенням періоду 2028-2033 років.

У 2015 р. в СС прийняті екологічні нормативи щчодо середніх спалювальних установок (1-50 МВт), які для нових установок вводяться в дію з 2018 , а для існуючих установок потужністю більше 5 МВт вводяться з 2025р, а для установок потужністю 1-5 МВт - з 2030р. В Украйні щодо середніх спалювальних установок технологічні екологічні нормативи прийняті тільки для спалювання лушпиння соняшнику, а для спалювання інших твердих палив діють екологічні нормативи загальні для всіх стаџіонарних джерел забруднення. При плануванні реконструкиії та продовженні експлуатації існуючих середніх енергетичних установок зі спалюванням лушпиння можна орієнтуватися на перспективні технологічні нормативи встановлені в Украӥні. В Україні граничнодопустимі викиди твердих часток загальні для всіх стаціонарних джерел забруднення при спалюванні твердого палива є нижчими, ніж вимоги стандарту EN 303-5:2012 до опалювальних котлів (до 500 кВт) третього класу, особливо при спалюванні торфу та соломи, тому є необхідність розробки первинних заходів для зменшення їх емісії до загальних вимог. Бібл. 24, табл. 11.

Ключові слова: спалювальна установка, котел, біомаса, спалювання, забруднюючі речовини, емісія, обмеження.

\section{PECULIARITIES OF APPLICATION OF THE NORMATIVE DOCUMENTS ON LIMITATION OF POLLUTANT EMISSIONS AT BIOMASS COMBUSTION}

\author{
M. Zhovmir ${ }^{1}$, candidate of technical sciences, M. Budko ${ }^{2}$, candidate of technical sciences
}

${ }^{1}$ Institute of Renewable Energy of NAS of Ukraine 02094 20A,Hnata Khotkevycha St., Kyiv, Ukraine

${ }^{2}$ National Technical University of Ukraine "Igor Sikorsky Kyiv Polytechnic Institute" 03056 37, Peremohy Avenue, Kyiv, Ukraine

The aim of work is to ascertain the impact of changes in the regulations on atmospheric air protection from pollution on further exploitation of existing and construction of new energy plants, development of new processes and boiler equipment for biomass burning. Paper provides an analysis of changes in the international documents, standards and normative acts of Ukraine concerning limitation of pollutants emission from energy plants with biomass combustion.

Recast EU directive provide environmental requirements for large combustion plants (above $50 \mathrm{MW}$ ) which are differentiated depending on their thermal input and valid for new plants since 2018, and for existing plants should be implemented in two stages since 2014 and 2028 years. For large combustion plants the regulations of Ukraine envisaged a gradual transition to EU environmental requirements till year 2033. Because of peculiarities of the modern environmental requirements introduction, biomass and coal co-firing at existing large power plants of Ukraine can become real close to the period of 2028-2033 years.

In 2015 the EU adopted environmental requirements for medium-sized combustion plants (1-50 MW) which are valid for new plants since 2018, and for existing plants with a thermal input more than $5 \mathrm{MW}$ they will enter into force in 2025, and at thermal input 1-5 $M W$ - in 2030. In Ukraine as to medium-sized combustion plant the technological environmental requirements are accepted only for sunflower husks usage combustion, but for other solid fuels burning the requirements common for all stationary sources of emissions are valid. At reconstruction and extending operation of the existing medium-sized husks combustion plants one can focus on perspective technological emission limitations established in Ukraine. In Ukraine the common particulate emission limitations at solid fuels combustion are lower, than that of the standard EN 303-5:2012 for boilers (up to 500 kW) of third class especially at burning peat and straw, so there is a need to develop primary measures for particulate emission reduction to common limitations. References 24 , tables 11 .

Key words: combustion plant, boiler, biomass, combustion, pollutants, emission, limitation.

(C) М.М. Жовмір, М.О. Будько, 2019 


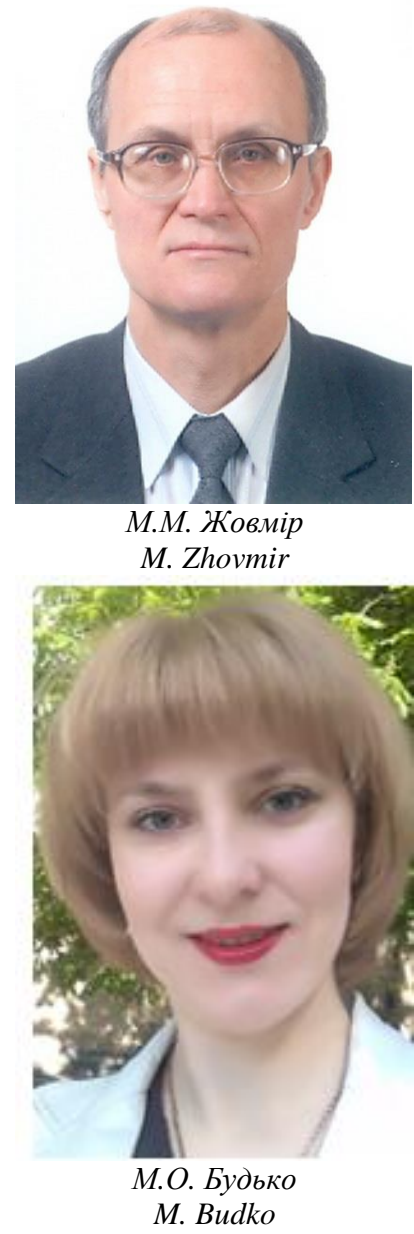

Відомості про автора: старший науковий співробітник відділу відновлюваних органічних енергоносіїв Інституту відновлюваної енергетики НАН України, старший науковий співробітник, кандидат технічних наук.

Освіта: Київський політехнічний інститут, теплоенергетичний факультет.

Наукова сфера: теплоенергетика, відновлювана енергетика, горіння твердих біопалив.

Публікації: 100 наукових публікацій, в тому числі 7 патентів.

ORCID: 0000-0001-6514-7474

Контакти: тел./факс: +38 (044) 206-28-09

e-mail: biomassa@ukr.net

Відомості про автора: старший викладач кафедри відновлюваних джерел енергії, Національний технічний університет України «Київський політехнічний інститут ім. I. Сікорського», кандидат технічних наук.

Освіта: Національний технічний університет України «Київський політехнічний інститут»,

інженер-біотехнолог за фахом «Промислова біотехнологія».

Наукова сфера: відновлювана енергетика, ефективність виробництва та використання біопалив, захист довкілля при використанні біопалив

Публікації: 22 наукові публікації.

Orcid: 0000-0003-0928-1657

Контакти: тел./факс: +38 (044) 204-81-91

e-mail: fialka93@gmail.com
Author information: Senior researcher, Department of renewable organic fuels, Institute of Renewable Energy of NAS of Ukraine, Senior Researcher, Candidate of Technical sciences.

Education: Kyiv Polytechnic Institute, Thermal Power Faculty.

Research area: Thermal power engineering, sustainable energy, solid biofuels burning.

Publications: 100 scientific publications, including 7 patents.

ORCID: 0000-0001-6514-7474

Contacts: tel./fax: +38 (044) 206-28-09

e-mail: biomassa@ukr.net

Author information: Senior lecturer, Department of Renewable Energy Sources, National Technical University of Ukraine «Igor Sikorsky Kyiv Polytechnic Institute»,

Candidate of Technical sciences.

Education: National Technical University of Ukraine "Kiev Polytechnic Institute", engineerbiotechnologist in the specialty "Industrial biotechnology".

Research area: sustainable energy, efficiency of biofuels production and usage, environment protection at biofuels usage

Publications: 22 scientific publications.

Orcid: 0000-0003-0928-1657

Contacts: tel./fax: +38 (044) 204-81-91

e-mail: fialka93@gmail.com
Вступ. Для збереження здоров'я людей, утримання рівня захворюваності та смертності населення на прийнятному рівні Всесвітньою організацією 3 охорони здоров'я (ВО3) встановлено рекомендовані показники щодо граничного вмісту у атмосферному повітрі основних чотирьох забруднюючих речовин - твердих часток, озону, оксидів азоту, оксидів сірки. Для країн Європи рекомендовані по- казники граничного вмісту згаданих забруднювачів наведено у табл. 1. Показник РМ10 відображає вміст часток розміром до 10 мкм і включає грубі частки (розміром від 2,5 до 10 мкм) та малі частки (розміром менше 2,5 мкм, - РМ2,5). Вважається, що саме малі частки викликають негативні наслідки для здоров'я, оскільки здатні проникати глибоко у легені [1].

Таблиця 1. Показники якості повітря рекомендовані ВОЗ [1].

Table 1. Indicatori of air quality recommended by WHO [1].

\begin{tabular}{|c|c|c|c|c|c|}
\hline & \multicolumn{5}{|c|}{ Середній вміст забруднюючих речовин, мкг/м ${ }^{3}$} \\
\hline & за 10 хвилин & за 1 годину & за 8 годин & за добу & за рік \\
\hline Малі тверді частки РМ2,5 & - & - & - & 25 & 10 \\
\hline Тверді частки РМ10 & - & - & - & 50 & 20 \\
\hline $\mathrm{O}_{30 \mathrm{O}} \mathrm{O}_{3}$ & - & - & 100 & - & - \\
\hline $\mathrm{NO}_{2}$ & - & 200 & - & 40 & - \\
\hline $\mathrm{SO}_{2}$ & 500 & & & 20 & \\
\hline
\end{tabular}

У продуктах спалювання біомаси основними забруднювачами є оксид вуглецю, оксиди азоту та тверді частки. Серед твердих часток особливо небажаними $є$ частки мікронного та субмікронного розмірів, уловлення яких є проблематичним [2]. У зв'язку з цим в ряді країн вводяться обмеження на спалювання біомаси в котлах та печах за несприятливих погодних умов, стимулюється перехід на електричне опалення, застосування теплових насосів та сонячних установок. Проте для багатьох країн, і України зокрема, стримування енергетичного використання біомаси $є$ неприйнятним, а тому необхідно поліпшувати екологічні показники енергоустановок з їі спалюванням. 
На початку 2000-х років міжнародними документами було унормовано викиди великих енергетичних установок тепловою потужністю $\mathrm{P} \geq 50$ МВт [3], а викиди малих та середніх енергетичних установок обмежувалися національними нормативними документами. На цей час уже встановлено міжнародні обмеження викиду забруднюючих речовин енергетичними установками потужністю $\mathrm{P} \geq 1 \mathrm{MB}$ відповідно до Директив СС $[4,5]$, вимоги яких Україна зобов'язується впровадити 3 приєднанням до Договору про заснування енергетичного співтовариства [6].

В Україні гранично допустимі викиди забруднюючих речовин від усіх стаціонарних джерел встановлені з 2007 р. національним нормативним документом - наказом Міністерства охорони навколишнього природного середовища України [7], а щодо окремих видів енергетичних установок встановлені технологічні нормативи допустимих викидів. Недавно внесено зміни у національні нормативні документи, введено у дію нові технічні стандарти на енергетичне обладнання.

Мета роботи. Необхідно 3'ясувати можливий вплив змін у нормативних документах щодо охорони атмосферного повітря від забруднення на подальшу експлуатацію існуючих та впровадження нових енергетичних установок, розробку нових процесів спалювання палив та постановку на виробництво нового котельного обладнання, зокрема, для спалювання біомаси та твердих біопалив. Аналіз вимог нормативних документів щодо емісії забруднюючих речовин при спалюванні біомаси, виконаний на основі нормативної бази станом на 2011 рік [8], потребує уточнення.

Аналіз застосування вимог Директив СС. У недавно прийнятій Директиві 2018/2001/СС «Про стимулювання використання енергії з відновлюваних джерел» дано уточнене визначення - «біомаса значить біорозкладувана частка продукції, відходів та залишків біологічного походження від сільського господарства, включаючи рослинні та тваринні речовини, від лісового господарства та відповідних виробництв, включаючи рибальство та аквакультуру, а також біорозкладувана частка відходів, включаючи промислові та муніципальні відходи біологічного походження» [9].

Директивою 2010/75/ЄС [4] в питаннях, що стосуються нормування викидів забруднюючих речовин від спалювання палив в енергетичних установках потужністю більше 50 МВт, «термін біомаса означає будь-яке з наступних понять:

(a) продукти, що складаються з будь-якої ро- слинної речовини, створені в результаті сільськогосподарської або лісницької діяльності, що можуть використовуватись як паливо для цілей утилізації їхньої енергетичної складової;

(b) наступні види відходів: рослинні відходи, створені в результаті сільськогосподарської або лісницької діяльності; рослинні відходи, створені в результаті діяльності харчової промисловості, якщо утворюване тепло утилізується; волокнисті рослинні відходи, створені в результаті обробки целюлози з первинної сировини та виробництва паперу з целюлозної сировини, якщо їх спалюють у місці виробництва, а утворюване тепло утилізується; луб'яні відходи; деревні відходи за винятком деревних відходів, що можуть містити галогеновані органічні сполуки або важкі метали в результаті обробки засобами попередження загнивання деревини або покриттями, та які включають, зокрема, деревні відходи, що утворені 3 відходів будівництва або знесення».

Як видно, визначення «біомаса» за Директивою 2010/75/СС [4], є вужчим у порівнянні 3 визначенням за Директивою 2018/2001/СС [9] і не включає до біомаси «...тваринних речовин» $\mathrm{i}$ «біорозкладуваної частки промислових та муніципальних відходів біологічного походження». Таким чином, біомасу неявно поділяють на чисту біомасу та відходи з подальшою диференціацією екологічних вимог до енергоустановок, що їх спалюють.

Директивою 2008/98/СС дано визначення «відходів» та «біовідходів» [10]. Перелік забруднюючих речовин та вимоги щодо гранично допустимого їх вмісту у газоподібних продуктах згорання відходів та небезпечних відходів встановлено Директивою 2000/76/ЄС «Про спалювання відходів» [11], які в подальшому були перевидані у Директиві 2010/75/СС «Про промислові викиди (інтегроване запобігання та контроль забруднення)» [4]. У табл. 2 та 3 наведено дані щодо граничнодопустимого викиду основних забруднюючих речовин при спалюванні відходів у перерахунку на сухі димові гази за нормальних фізичних умов та вмісту кисню $11 \%$ об. Стосовно димових газів від спалювання відходів також встановлені граничнодопустимі концентрації важких металів та їх сполук в перерахунку на викид металу для кадмію, талію, ртуті, сурми, миш'яку, свинцю, хрому, кобальту, міді, марганцю, нікелю та ванадію за період вимірювання тривалістю від 30 хвилин до 8 годин; емісія діоксинів та фуранів (перерахована за концепцією токсичних еквівалентів) за період вимірювання тривалістю від 6 до 8 годин. 
Таблиця 2. Середня добова граничнодопустима емісія у продуктах згорання відходів [4].

Table 2. Daily average emission limit values in the flue gas of waste combustion [4].

\begin{tabular}{|c|c|c|}
\hline & Показник & Значення \\
\hline 1 & Загальний вміст твердих часток, мг/м ${ }^{3}$ & 10 \\
\hline 2 & 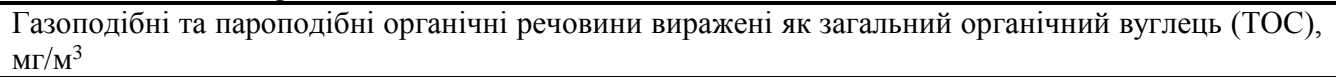 & 10 \\
\hline 3 & $\mathrm{HCl}, \mathrm{M \Gamma} / \mathrm{M}^{3}$ & 10 \\
\hline 4 & $\mathrm{HF}, \mathrm{M \Gamma} / \mathrm{M}^{3}$ & 1 \\
\hline 5 & $\mathrm{SO}_{2}, \mathrm{M} \Gamma / \mathrm{M}^{3}$ & 50 \\
\hline 6 & 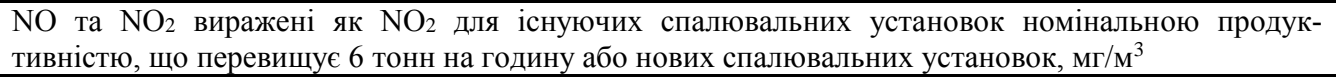 & 200 \\
\hline 7 & $\begin{array}{l}\mathrm{NO} \text { та } \mathrm{NO}_{2} \text { виражені як } \mathrm{NO}_{2} \text { для існуючих спалювальних установок номінальною продуктивністю } \\
6 \text { тонн на годину або менше, мг } / \mathrm{M}^{3}\end{array}$ & 400 \\
\hline
\end{tabular}

Таблиця 3. Гранично допустима концентрація СО у продуктах згорання відходів [4].

Table 3. Emission limit values for $\mathrm{CO}$ in the flue gas of waste combustion [4].

\begin{tabular}{|c|c|c|}
\hline & Показник & Значення \\
\hline 1 & Середня за добу концентрація CO, мг/м ${ }^{3}$ & 50 \\
\hline 2 & $\begin{array}{l}\text { Середня концентрація СО, виміряна за 30-хвилинні інтервали протягом будь-якого 24-годинного } \\
\text { періоду, мг/м }\end{array}$ & 100 \\
\hline 3 & $\begin{array}{l}\text { Середня концентрація СО, виміряна за 10-хвилинні інтервали (95 \% результатів всіх вимірювань), } \\
\text { мг/м }\end{array}$ & 150 \\
\hline
\end{tabular}

Спочатку Директивою 2001/80/СС [3] і в подальшому Директивою 2010/75/СС [4] встановлено граничні викиди забруднюючих речовин в атмосферне повітря при спалюванні чистої біомаси у великих енергетичних установках сукупною ефективною тепловою потужністю по паливу $\mathrm{P}>50$ МВт. Документами встановлюються граничні показники емісії кислих газів $\left(\mathrm{SO}_{2}\right.$, $\mathrm{NO}_{\mathrm{x}}$, як причини кислих дощів, та твердих часток, як таких, що зумовлюють транскордонне перенесення важких металів. В табл. 4 наведено значення гранично допустимих концентрацій забруднюючих речовин для великих енергоустановок зі спалюванням чистої біомаси залежно від дати введення їх в експлуатацію (в перерахунку на сухі гази за нормальних умов та вмісту кисню 6\%об.). Відповідно до рішення Ради Міністрів Енергетичного Співтовариства від 24 жовтня 2013 р. вимоги Директиви 2010/75/ЄС набувають чинності в Енергетичному Співтоваристві для всіх великих спалювальних установок після 31 грудня 2027 року [12].

Таблиця 4. Граничнодопустимі викиди при спалюванні біомаси у великих спалювальних установках [4].

Table 4. Emission limit values at biomass burning in large combustion plants [4].

\begin{tabular}{|c|c|c|c|}
\hline $\begin{array}{c}\text { Сукупна номінальна ефективна теплова } \\
\text { потужність, МВт }\end{array}$ & $\mathrm{SO}_{2}, \mathrm{M \Gamma} / \mathrm{M}^{3}$ & $\mathrm{NO}, \mathrm{Mr} / \mathrm{M}^{3}$ & $\begin{array}{l}\text { Пил (тверді частки), } \\
\text { мг/м³ }\end{array}$ \\
\hline \multicolumn{4}{|c|}{ Енергоустановки, що отримали дозволи на викиди до 7.01. 2013 р. та введені в експлуатацію до 7.01 .2014 р. } \\
\hline $50-100$ & 200 & 300 & 30 \\
\hline $100-300$ & 200 & 250 & 20 \\
\hline$>300$ & 200 & 200 & 20 \\
\hline \multicolumn{4}{|c|}{$\begin{array}{l}\text { Нові та реконструйовані енергоустановки, що вводяться в експлуатацію після 7.01.2014 p., а також установки, яким надава } \\
\text { лися винятки Директивою 2001/80/СС, та які продовжують експлуатуватися після } 1.01 .2016 \text { p. }\end{array}$} \\
\hline $50-100$ & 200 & 250 & 20 \\
\hline $100-300$ & 200 & 200 & 20 \\
\hline$>300$ & 150 & 150 & 20 \\
\hline
\end{tabular}

Директивою 2015/2193/СС «Про обмеження викиду забруднюючих речовин в атмосферне повітря від середніх спалювальних установок» [5] введено граничнодопустимі викиди забруднюючих речовин від існуючих та нових енергоустановок потужністю $\mathrm{P}=1 \ldots 50$ МВт по паливу. В таблиці 5 наведено значення гранично допустимих концентрацій забруднюючих речовин для існуючих та нових енергоустановок зі спалюванням чистої біома- си залежно від їхньої потужності та дату набрання чинності встановлених вимог (в перерахунку на сухі гази за нормальних умов та вмісту кисню $6 \%$ об.). Існуючими енергоустановками вважаються енергоустановки, для яких отримано дозволи на викиди до 19 грудня 2017 р. та які введено в експлуатацію не пізніше 20 грудня 2018 р., а новими вважаються установки, які пізніше проходили процедуру погодження та введення в експлуатацію. 
Таблиця 5. Граничнодопустимі викиди при спалюванні біомаси в середніх спалювальних установках [5].

Table 5. Emission limit values at biomass burning in medium combustion plants [5].

\begin{tabular}{|c|c|c|}
\hline & $\begin{array}{c}\text { Номінальна теплова потужність енерго- } \\
\text { установки } 1 \mathrm{MBT}<\mathrm{P} \leq 5 \mathrm{MB}\end{array}$ & $\begin{array}{c}\text { Номінальна теплова потужність енерго- } \\
\text { установки } 5 \mathrm{MB}<\mathrm{P} \leq 50 \mathrm{MBT}\end{array}$ \\
\hline \multicolumn{3}{|l|}{ Існуючі енергоустановки } \\
\hline $\mathrm{SO}_{2, \mathrm{M} \Gamma} / \mathrm{M}^{3}$ & $\begin{array}{l}200 \text { (не застосовується при спалюванні } \\
\text { деревної біомаси) } \\
300 \text { (при спалюванні соломи) }\end{array}$ & $\begin{array}{l}200 \text { (не застосовується при спалюванні де- } \\
\text { ревної біомаси) } \\
300 \text { (при спалюванні соломи) }\end{array}$ \\
\hline $\mathrm{NO}_{\mathrm{X}}, \mathrm{M \Gamma} / \mathrm{M}^{3}$ & 650 & 650 \\
\hline 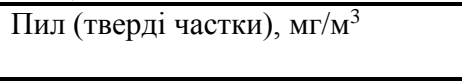 & 50 & $\begin{array}{l}50 \text { (при } 5 \mathrm{MBT}<\mathrm{P} \leq 20 \mathrm{MBT}) \\
30 \text { (при } \mathrm{P}>20 \mathrm{MBT})\end{array}$ \\
\hline Термін набрання чинності вимог & 1 січня 2030 p. & 1 січня 2025 p. \\
\hline \multicolumn{3}{|c|}{ Нові та реконструйовані енергоустановки } \\
\hline $\mathrm{SO}_{2}, \mathrm{M} \Gamma / \mathrm{M}^{3}$ & $\begin{array}{l}200 \text { (не застосовується при спалюванні } \\
\text { деревної біомаси) }\end{array}$ & $\begin{array}{l}200 \text { (не застосовується при спалюванні де- } \\
\text { ревної біомаси) }\end{array}$ \\
\hline $\mathrm{NOx}, \mathrm{M \Gamma} / \mathrm{M}^{3}$ & 500 & 300 \\
\hline Пил (тверді частки), мг/м³ & 50 & $\begin{array}{l}30 \text { (при } 5 \mathrm{MBT}<\mathrm{P} \leq 20 \mathrm{MBT} \text { ) } \\
20 \text { (при } \mathrm{P}>20 \mathrm{MBT} \text { ) }\end{array}$ \\
\hline Термін набрання чинності вимог & 20 грудня 2018 р. & 20 грудня 2018 р. \\
\hline
\end{tabular}

Директивами 2010/75/ЄC [4] та 2015/2193/СC [5] передбачена можливість та умови тимчасового відступу від встановлених вимог 3 огляду на обставини, що виникають при експлуатації енергоустановок в ізольованих енергосистемах, в системах централізованого теплопостачання; енергоустано-вок, які експлуатуються обмежений час, експлуатуються у випадках аварій та за аномально холодної погоди.

Аналіз застосування вимог нормативних документів Украӥни. В 2007 р Міністерством охорони навколишнього природного середовища України прийнято нормативи щодо гранично допустимих викидів із стаціонарних джерел [7]. За цим документом стосовно спалювання твердих палив можна визначити гранично допустимі концентрації у продуктах згорання (в перерахунку на сухі гази за нормальних умов та вмісту кисню $6 \%$ об.) основних забруднювачів атмосферного повітря: твердих часток, оксидів сірки, оксидів азоту та оксиду вуглецю (табл. 6).

Таблиця 6. Граничнодопустимі викиди при спалюванні твердих палив від стаціонарних джерел [7].

Table 6. Emission limit values at solid fuels from stationary sources [7].

\begin{tabular}{|l|l|l|}
\hline Назва речовини & $\begin{array}{l}\text { Величина годинного викиду, } \\
\text { г/год }\end{array}$ & $\begin{array}{l}\text { Гранично допустима концентрація в } \\
\text { димових газах, мг/м3 }\end{array}$ \\
\hline Тверді частки, недиференційовані за складом & Більше 500 & 50 \\
\cline { 2 - 3 } & Менше 500 & 150 \\
\hline Оксиди сірки в перерахунку на $\mathrm{SO}_{2}$ & 5000 і більше & 500 \\
\hline Оксиди азоту в перерахунку на $\mathrm{NO}_{2}$ & 5000 і більше & 500 \\
\hline Оксид вуглецю & 5000 і більше & 250 \\
\hline
\end{tabular}

В Україні вимоги згаданих вище Директив ЄC впроваджуються шляхом прийняття національних нормативних документів - технологічних нормативів, якими встановлюються кориговані цільові показники та строки їх введення в дію $з$ врахуванням стану енергетичного сектору та економіки в цілому. У 2008 р. в Україні введено технологічні нормативи допустимих викидів забруднюючих речовин від великих енергоустановок номінальною потужністю понад $50 \mathrm{MBT}$ [13]. В 2015 та 2018 роках цей документ було переглянуто і встановлено нові поточні та перспективні технологічні нормативи. Щодо установок зі спалюванням біомаси документом на даний час введено лише перспективні технологічні нормативи для нових та модернізованих установок, що споруджуються та вводяться в експлуатацію на основі проектно-кошторисної документації, затвердженої після 1 січня 2018 р., причому ці нормативи співпадають 3 вимогами Директиви 2010/75/ЄС до нових енергоустановок (див. табл. 4). Крім того в Україні для великих енергетичних установок встановлено гранично допустимий викид оксиду вуглецю $250 \mathrm{Mг} / \mathrm{M}^{3}$ [13].

Національним планом скорочення викидів [14] намічено, що в Україні великі спалювальні установки мають досягти нормативів граничнодопустимих викидів забруднюючих речовин та інших вимог, викладених у Директиві 2010/75/СС, - до 31 грудня 2028 року для пилу і $\mathrm{SO}_{2}$ та до 31 грудня 2033 року для $\mathrm{NO}_{\mathrm{x}}$. Після завершення строків дії Національного плану скорочення викидів оператори великих спалювальних установок мають дотримуватися граничних значень викидів відповідно до 
вимог Директиви 2010/75/СС.

У 2009 р. в Україні введено технологічні нормативи допустимих викидів забруднюючих речовин від котелень, що працюють на лушпинні соняшнику, оснащених теплосиловими установками номінальною тепловою потужністю менше 50 МВт [15]. У 2016 р. до цього документу було внесено зміни. Для існуючих енергетичних установок, що споруджені за проектно-кошторисною документацією, затвердженою до 01.12.2009, діють поточні технологічні нормативи, наведені у табл. 7, при цьому нормативи щодо викиду твердих часток, оксидів азоту, оксиду вуглецю чинні до 31.12.2017, а після цього терміну мають застосовуватися нормативи як для нових установок. Для нових та модернізованих установок, що споруджені за проектно-кошторисною докумен-тацією, затвердженою після 01.12.2009, встановлено перспективні технологічні нормативи 3 диференціацією залежно від їх потужності, що наведені у табл. 8 (табл. 7 та 8 значення наведені для сухих димових газів за нормальних умовах та вмісту кисню $\mathrm{O}_{2}=11 \%$ ). Можна очікувати, що зазначені технологічні нормативи в недалекому майбутньому будуть поступово приводитись у відповідність 3 більш жорсткими вимогами Директиви 2015/2193/ЄС [5].

Таблиця 7. Поточні технологічні нормативи викиду забруднюючих речовин для існуючих енергоустановок, що спалюють лушпиння соняшнику [15].

Table 7. Current technological emission limits for existing energy installations at sunflower husks combustion [7].

\begin{tabular}{|c|c|c|c|}
\hline Забруднююча речовина & Технологічні особливості & $\begin{array}{c}\text { Технологічні нормативи допусти- } \\
\text { мого викиду, мг } / \mathrm{M}^{3} \text { при } 11 \% \mathrm{O}_{2}\end{array}$ & Термін дії \\
\hline \multirow{2}{*}{$\begin{array}{l}\text { Суспендовані тверді частки } \\
\text { недиференційовані за складом }\end{array}$} & Пилоочисна установка - електрофільтр & 100 & \multirow{4}{*}{$\begin{array}{c}\text { Дійсні до } \\
\text { 31.12.2017 } \\
\text { p. }\end{array}$} \\
\hline & Пилоочисна установка - циклон & 600 & \\
\hline \multirow{2}{*}{$\mathrm{CO}$} & Спалювання - вихрове & 2250 & \\
\hline & Спалювання - шарове & 750 & \\
\hline $\mathrm{NOx}\left(\right.$ як $\left.\mathrm{NO}_{2}\right)$ & & 300 & \\
\hline $\mathrm{SO}_{2}$ & - & 250 & - \\
\hline
\end{tabular}

Таблиця 8. Перспективні технологічні нормативи викиду забруднюючих речовин новими та реконструйованими енергоустановками, що спалюють лушпиння соняшнику [15].

Table 8. Perspective technological emission limits for new and reconstructed energy installations at sunflower husks combustion [15].

\begin{tabular}{|l|c|c|}
\hline \multirow{2}{*}{$\begin{array}{l}\text { Забруднююча } \\
\text { речовина }\end{array}$} & \multicolumn{2}{|c|}{ Технологічні нормативи допустимого викиду, мг/м ${ }^{3}$, при $11 \%$ О2 } \\
\cline { 2 - 3 } & Потужність енергоустановки по паливу, МВт \\
\cline { 2 - 3 } & $\mathrm{P}<5$ & $5 \leq \mathrm{P}<50$ \\
\hline Тверді частки & 100 & 50 \\
\hline $\mathrm{SO}_{2}$ & 250 & 250 \\
\hline $\mathrm{NO}_{\mathbf{X}}\left(\right.$ як $\left.\mathrm{NO}_{2}\right)$ & 300 & 300 \\
\hline $\mathrm{CO}$ & 250 & 250 \\
\hline
\end{tabular}

Аналіз застосування вимог чинних в Україні стандартів на парові та водогрійні котли. В Україні на електричних станціях загального користування, що працюють на твердому паливі, встановлено парові котли великої потужності, переважно паропродуктивністю від 160 до 950 т/год, які конструювали та виготовляли відповідно до вимог, аналогічних ГОСТ 28269 89. Цим стандартом встановлювалася граничнодопустима емісія лише для оксидів азоту. Так для парогенераторів зі спалюванням кам'яного вугілля та антрациту з рідким видаленням шлаку допускалась емісія оксидів азоту до 640-800 мг/м [16]. Для електричних станцій України характерна значна емісія забруднюючих речовин: твердих

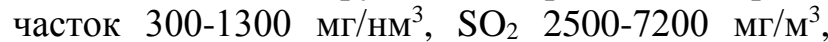

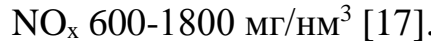

За літературними даними сумісне спалювання біомаси та вугілля на існуючих великих елек- тричних станціях розглядається як шлях найбільш ефективного іï використання для виробництва електричної енергії. Проте в Україні викиди реконструйованих енергоустановок мають відповідати перспективним технологічним нормативам для палива 3 найгіршими екологічними показниками [13]. Зважаючи на необхідність значних капітальних вкладень не тільки на організацію спалювання біомаси, але і одночасне досягнення граничнодопустимої емісії забруднюючих речовин для спалювання основного палива, можна допустити, що поліпшення екологічних показників великих електростанцій за рахунок сумісного спалювання біомаси 3 вугіллям не буде відноситися до пріоритетів їх операторів. На реалізацію подібних проектів можна надіятися лише 3 наближенням періоду 20282033 років, коли виконання вимог Директиви 2010/75/ЄС стане невідворотним в Україні. 
Котельні промислових підприємств, що споживають тверде паливо, переважно оснащені паровими котлами на тиск пари $13 \ldots 39$ бар та паропродуктивністю від 4 до 50 т/год. Ці котли конструювали та виготовляли відповідно до вимог аналогічних ГОСТ 24005-80, але цей стандарт не встановлював вимог щодо обмеження викиду забруднюючих речовин [18]. На час розробки цих котлів прийнятна величина втрат енергії через хімічний недопал опосередковано визначала емісію оксиду вуглецю; обмеження викидів оксидів сірки досягалось використанням палив 3 прийнятним вмістом сірки, обмеження викидів твердих часток досягалось вибором технології спалювання, циклонів, мокрих скруберів, скорочення викидів азоту досягалось реалізацією первинних заходів. Ряд таких котлів переведено на споживання деревних відходів або відходів переробки сільськогосподарської сировини на основі індивідуальних проектів 3 дотриманням екологічних вимог нормативних документів, чинних на час їх реконструкції.

Котельні невеликих підприємств харчової промисловості та лісового господарства оснащені паровими котлами на тиск пари 9 ... 13 бар та паропродуктивністю від 1,0 .. 2,5 т/год., які конструювали та виготовляли відповідно до вимог ГОСТ 28193-89. Стандартом встановлено максимально допустимі викиди при спалюванні кам'яного вугілля: оксиду вуглецю - $375 \mathrm{mг} / \mathrm{M}^{3}$ та оксидів азоту $750 \mathrm{Mг} / \mathrm{M}^{3}$ (в перерахунку на сухі нерозведені продукти згорання при нормальних умовах) [19]. Такі котли масово переведені на спалювання різних видів біомаси зі збільшенням об'єму топки, влаштуванням передтопків, механізованих топок або топок з ручним обслуговуванням.

Котли водогрійні теплопродуктивністю 0,63 - 209 МВт $з$ температурою підігріву води 95 $200{ }^{\circ} \mathrm{C}$ відповідно до ГОСТ 21563-93 [20] створювались для систем централізованого теплопо- стачання як основні $(0,63 \ldots 35$ МВт), так і пікові $(58,2 \ldots 209$ МВт) джерела теплоти. Стандартом встановлено вимоги щодо допустимих викидів оксидів азоту при спалюванні газу (230$\left.300 \mathrm{Mr} / \mathrm{M}^{3}\right)$, мазуту $\left(340-380 \mathrm{Mr} / \mathrm{M}^{3}\right)$, бурого $(400$

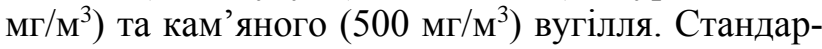
том не встановлено вимоги щодо емісії забруднюючих речовин при використанні біомаси та торфу. В Україні були невдалі спроби спалювання деревної тирси у водогрійному котлі теплопродуктивністю 116 МВт з топкою, що призначалась для факельного спалювання вугілля.

Котли опалювальні водогрійні теплопродуктивністю $0,10-4,0$ МВт 3 температурою нагріву води до $115{ }^{\circ} \mathrm{C}$ тиском до 6 бар відповідно до ГОСТ 30735-2001 [21] створювались для теплопостачання будівель і споруд 3 системами опалення 3 номінальним перепадом температур $95-70^{\circ} \mathrm{C}$ та $115-70^{\circ} \mathrm{C}$. Котли призначаються для спалювання газу, легкого та важкого рідкого палива, бурого та кам'яного вугілля, антрациту, деревини та торфу. Стандартом встановлено гранично допустимий вміст у продуктах згорання оксиду вуглецю та оксидів азоту для спалювання газу та рідкого палива, а для спалювання твердих палив нормується лише вміст СО залежно від виду палива, потужності та класу котла (в перерахунку на сухі продукти згорання при нормальних умовах з коефіцієнтом надлишку повітря $\alpha=1,0$; табл. 9). Сталеві водогрійні котли за ГОСТ 30735-2001 мають широке розповсюдження в Україні, зокрема, для спалювання дров та кускових деревних відходів з ручним обслуговуванням, спалювання тирси i тріски 3 механізованою подачею палива. Подальша експлуатація цих котлів потребує впровадження заходів зі зниження емісії забруднюючих речовин до встановлених вимог [7], особливо для котлів верхнього діапазону теплопродуктивності.

Таблиця 9. Вміст СО у продуктах згорання твердого палива для котлів по ГОСТ 30735-2001 [21].

Table 9. Content of CO in flue gas at solid fuels combustion in boilers according to GOST 30735-2001 [21].

\begin{tabular}{|c|c|c|c|c|}
\hline \multirow{2}{*}{$\begin{array}{c}\text { Вид палива та тип } \\
\text { топкового пристрою }\end{array}$} & \multirow{2}{*}{$\begin{array}{c}\text { Номінальна тепло- } \\
\text { продуктивність котла, МВт }\end{array}$} & \multicolumn{3}{|c|}{ Вміст СО в сухих нерозведених продуктах згорання, мг/м ${ }^{3}$} \\
\hline & & Клас I & Клас II & Клас III \\
\hline \multicolumn{5}{|c|}{ Котли для твердого палива з ручною топкою } \\
\hline \multirow{3}{*}{$\begin{array}{l}\text { Кам'яне вугілля з вихо- } \\
\text { дом летких речовин біль- } \\
\text { ше } 10 \%\end{array}$} & 0,1 до 0,3 & 4500 & 9000 & 24000 \\
\hline & 0,3 до 0,5 & 3600 & 7200 & 24000 \\
\hline & 0,5 до 0,8 & 3000 & 6000 & 24000 \\
\hline Деревина, торф & 0,1 до 0,3 & 5000 & 10000 & 24000 \\
\hline \multicolumn{5}{|c|}{ Котли для твердого палива з механічною топкою } \\
\hline \multirow{3}{*}{$\begin{array}{l}\text { Антрацит та кам'яне ву- } \\
\text { гілля }\end{array}$} & 0,1 до 0,5 & 2000 & 3600 & 12000 \\
\hline & 0,5 до 1,0 & 1200 & 2000 & 8000 \\
\hline & 1,0 до 4,0 & 750 & 1500 & 6000 \\
\hline \multirow[t]{3}{*}{ Деревина, торф } & 0,1 до 0,5 & 2500 & 4200 & 24000 \\
\hline & 0,5 до 1,0 & 2200 & 3700 & 24000 \\
\hline & 1,0 до 4,0 & 2000 & 3300 & 24000 \\
\hline
\end{tabular}


Котли опалювальні водогрійні 3 температурою підігріву води до $95^{\circ} \mathrm{C}$ та теплопродуктивністю до 100 кВт відповідно до ГОСТ 20548-87 (ДСТУ 2326-93) [22] для спалювання вугілля, рідкого та газового палива виробляються в Україні рядом заводів. Стандартом встановлено вимоги щодо граничнодопустимого вмісту оксиду вуглецю та оксидів азоту при спалюванні легкого рідкого палива та природного газу. При спалюванні твердих палив обмежується вміст оксиду вуглецю: для кам'яного вугілля до $24-48$ г/м ${ }^{3}$ та для антрациту $10 \mathrm{r} / \mathrm{M}^{3}$ в сухих нерозведених продуктах згорання при нормальних умовах; екологічні показники при спалюванні твердих біопалив не встановлено. Такі котли мають значене поширення у побуті, соціальній та виробничій сферах, часто їх експлуатують 3 використанням непроектних палив - брикетів торф'яних, дров та кускових деревних відходів. Для котлів потужністю до 50 кВт не обов'язкові екологотеплотехнічні випробування та налагодження [23], внаслідок цього такі котли експлуатуються зі значною неконтрольованою емісією забруднюючих речовин. Широкому застосуванню цих котлів сприяє і те, що котли теплопродуктивністю до 100 кВт не підпадають під державний нагляд у сфері безпеки посудин, що працюють під тиском вище атмосферного.

В кінці 2014 р. прийнято міждержавний стандарт ГОСТ 33016-2014 на котли опалювальні номінальною тепловою потужністю до 500 кВт 3 температурою підігріву води до $110^{\circ} \mathrm{C}$, тиском до 6 бар для твердого палива 3 ручним та автоматичним завантаженням [24], який є модифікацією стандарту EN 303-5:2012. Стандартом встановлено гранично допустимий вміст у продуктах згорання оксиду вуглецю, летких органічних сполук, пилу (твердих часток) при спалюванні різних видів твердого палива. За цим стандартом викопні палива поділяють на класи з відповідними позначеннями: $\boldsymbol{a}$ - кам'яне вугілля; $\boldsymbol{b}$ - буре вугілля; $\boldsymbol{c}$ - кокс; $\boldsymbol{d}$ - антрацит; $\boldsymbol{e}$ - торф, а біогенні види палива (відновлювані тверді біопалива) мають наступну класифікацію: $\boldsymbol{A}$ - кускова деревина (дрова) 3 вмістом вологи до $25 \%$; B1 - подрібнена деревина (тріска) 3 корою та без кори 3 частками максимальним розміром до 15 мм з вмістом вологи від $15 \%$ до $35 \%$; $\boldsymbol{B 2}$ подрібнена деревина як В1, але із вмістом вологи більше $35 \%$; $\boldsymbol{C 1}$ - пресована деревина (пелети без в'яжучої речовини, виготовлені 3 деревини та/або кори; допускаються природні в'яжучі речовини - патока, рослинні парафіни і крохмаль); $\boldsymbol{C 2}$ - пресована деревина (брикети без в'яжучих речовин 3 деревини та /або кори, допускаються природні в'яжучі речовини - патока, рослинні парафіни і крохмаль); $\boldsymbol{D}$ - тирса з вмістом вологи до $50 \% ; \boldsymbol{E}$ - недеревна біомаса: солома, очерет, комиш, макуха та шрот з горіхів і насіння.

Згідно з ГОСТ 33016-2014 (ЕN 303-5:2012) [24] при випробуванні котлів 3 метою встановлення їхніх технічних та екологічних характеристик мають застосовуватися палива 3 властивостями наведеними у таблиці 10 . Цим стандартом залежно від виду палива та потужності котлів встановлено значення гранично допустимих викидів забруднюючих речовин у сухих продуктах згорання за нормальних умов та референтному вмісті кисню у продуктах згоряння $10 \%$ об. Чинним в Україні нормативним документом [7] граничнодопустимі викиди встановлені при референтній концентрації кисню - 6 \% об. У зв'язку з цим значення вимог стандарту [24] перерахували на референтну концентрацію кисню $6 \%$ з застосуванням залежності, наведеної у Директиві 2010/75/ЄC (додаток VI) [4], результати перерахунку наведено у таблиці 11 в дужках.

Таблиця 10. Вимоги до твердих біопалив для випробування котлів по ГОСТ 33016-2014 [24].

Table 10. Specification of fuels for testing boilers according to GOST 33016-2014 [24].

\begin{tabular}{|l|l|l|l|l|l|}
\hline Вид палива & \multirow{2}{*}{ Клас палива } & $\begin{array}{l}\text { Вміст воло- } \\
\text { ги Вміст золи }\end{array}$ & $\begin{array}{l}\text { Леткі } \\
\text { вини }\end{array}$ & $\begin{array}{l}\text { речо- } \\
\text { реплота зго- } \\
\text { рання }\end{array}$ \\
\cline { 3 - 5 } & & $\%$ & $\%$ & $\%$ & МДж/кг \\
\hline Кускова деревина (дрова) & $\mathrm{A}$ & $15-20$ & 1 & - & $>17$ \\
\hline Тріска & $\mathrm{B} 1$ & $20-30$ & 1,5 & - & $>17$ \\
\cline { 2 - 5 } & $\mathrm{B} 2$ & $40-50$ & 1,5 & - & \\
\hline $\begin{array}{l}\text { Пресовані відходи } \\
\text { (гранули, брикети) }\end{array}$ & $\mathrm{C}$ & 12 & 0,5 & - & $>17$ \\
\hline Тирса & $\mathrm{D}$ & $35-50$ & 0,5 & - & $>17$ \\
\hline Недеревна біомаса & $\mathrm{E}, \mathrm{e}$ & 3а специфікаціями виробників & $>16$ \\
\hline
\end{tabular}


Таблиця 11. Гранично допустимі викиди забруднюючих речовин при спалюванні твердих палив в опалювальних котлах за ГОСТ 33016-2014 [24].

Table 11. Emission limit values at solid fuels burning in heating boilers according to GOST 33016-2014 [24].

\begin{tabular}{|c|c|c|c|c|c|c|c|c|c|}
\hline \multirow{4}{*}{$\begin{array}{c}\text { Номінальна теплопродук- } \\
\text { тивність, кВт }\end{array}$} & \multicolumn{9}{|c|}{ Граничнодопустимі викиди забруднюючих речовин, мг/м³ } \\
\hline & \multicolumn{3}{|c|}{$\mathrm{CO}$} & \multicolumn{3}{|c|}{ Леткі органічні сполуки } & \multicolumn{3}{|c|}{ Пил (тверді частки) } \\
\hline & \multicolumn{9}{|c|}{ Клас котла } \\
\hline & 3 & 4 & 5 & 3 & 4 & 5 & $3 *$ & 4 & 5 \\
\hline \multicolumn{10}{|c|}{ Котли з ручним завантаженням палива } \\
\hline$\leq 50$ & $\begin{array}{c}5000 \\
(6818) \\
\end{array}$ & \multirow{3}{*}{$\begin{array}{c}1200 \\
(1636)\end{array}$} & \multirow{3}{*}{$\begin{array}{c}700 \\
(955)\end{array}$} & $\begin{array}{c}150 \\
(205) \\
\end{array}$ & \multirow{3}{*}{$\begin{array}{c}50 \\
(68)\end{array}$} & \multirow{3}{*}{$\begin{array}{c}30 \\
(41)\end{array}$} & $\begin{array}{c}150 \\
(205) \\
\end{array}$ & \multirow{3}{*}{$\begin{array}{c}75 \\
(102)\end{array}$} & \multirow{3}{*}{$\begin{array}{c}60 \\
(82)\end{array}$} \\
\hline$>50 \leq 150$ & $\begin{array}{c}2500 \\
(3409)\end{array}$ & & & $\begin{array}{c}100 \\
(136)\end{array}$ & & & $\begin{array}{c}150 \\
(205)\end{array}$ & & \\
\hline$>150 \leq 500$ & $\begin{array}{c}1200 \\
(1636)\end{array}$ & & & $\begin{array}{c}100 \\
(136)\end{array}$ & & & $\begin{array}{c}150 \\
(205)\end{array}$ & & \\
\hline \multicolumn{10}{|c|}{ Котли з автоматичним завантаженням палива } \\
\hline$\leq 50$ & $\begin{array}{c}3000 \\
(4090) \\
\end{array}$ & \multirow{3}{*}{$\begin{array}{c}1000 \\
(1364)\end{array}$} & \multirow{3}{*}{$\begin{array}{c}500 \\
(682)\end{array}$} & $\begin{array}{c}100 \\
(136) \\
\end{array}$ & \multirow{3}{*}{$\begin{array}{c}30 \\
(41)\end{array}$} & \multirow{3}{*}{$\begin{array}{c}20 \\
(27)\end{array}$} & $\begin{array}{c}150 \\
(205) \\
\end{array}$ & \multirow{3}{*}{$\begin{array}{c}60 \\
(82)\end{array}$} & \multirow{3}{*}{$\begin{array}{c}40 \\
(55)\end{array}$} \\
\hline$>50 \leq 150$ & $\begin{array}{c}2500 \\
(3409) \\
\end{array}$ & & & $\begin{array}{c}80 \\
(109) \\
\end{array}$ & & & $\begin{array}{c}150 \\
(205) \\
\end{array}$ & & \\
\hline$>150 \leq 500$ & $\begin{array}{c}1200 \\
(1636)\end{array}$ & & & $\begin{array}{c}80 \\
(109)\end{array}$ & & & $\begin{array}{c}150 \\
(205)\end{array}$ & & \\
\hline
\end{tabular}

Як видно з наведених даних, котли 3-го класу за викидом твердих часток можуть не відповідати вимогам чинного в Україні нормативу [7], і при їхному застосуванні може бути необхідним встановлення додаткових позакотлових пристроїв очищення димових газів від твердих часток, особливо при спалюванні соломи та торфу. В опалювальних котельнях такі котли зазвичай експлуатуються без додаткових систем очищення димових газів, а тому актуальним завданням $\epsilon$ розробка первинних заходів щодо зменшення емісії твердих часток навіть для стандартних котлів, що виробляються у країнах $\mathrm{CC}$ та ввозяться в Україну, зокрема для спалювання соломи та торфу.

Висновки 1.Термін експлуатації великих енергетичних установок для спалювання біомаси значно більше ніж запланований часовий період переходу від поточних до перспективних технологічних нормативів гранично допустимого викиду забруднюючих речовин, а тому при продовжені експлуатації існуючих енергетичних установок доцільно орієнтуватися на перспективні технологічні нормативи встанов-лені в Україні, а при створенні нових установок, розробці процесів спалювання палив та відповідного енергетичного обладнання необхідно орієнтуватися на показники не гірші, ніж встановлені Директивами СС.

2. Зважаючи на зниження граничнодопустимих викидів від середніх енергетичних установок для продовження їхньої експлуатації необхідні розробка та впровадження нових заходів щодо зменшення емісії забруднюючих речовин при спалюванні біомаси.

3. Вимоги чинних в Україні нормативних документів щодо гранично допустимих викидів твердих часток при спалюванні біомаси та твердих біопалив у опалювальних котлах (до 500 кВт) є жорсткішими порівняно з вимогами стандарту EN 303-5:2012 стосовно простих котлів третього класу, особливо при спалюванні соломи та торфу.

4. У зв'язку з необхідністю широкого використання біомаси та твердих біопалив з застосуванням опалювальних котлів (до 500 кВт) актуальним завданням $\epsilon$ розробка для них первинних заходів щодо зменшення емісії твердих часток до загальних вимог чинних в Україні.

1. WHO air quality guidelines for particulate matter, ozone, nitrogen dioxide and sulfur dioxide. Global update 2005. Summary of risk assessment. World Health Organization. Geneva. 2006. 22 p. URL:

http://www.who.int/airpollution/publications

2. Aerosols from biomass combustion. NussbaumerTh. (Ed.). Zurich, 2001. 107 p. URL: verenum@access.ch

3. Directive 2001/80/EC of the European Parliament and of the Council of 23 October 2001 on the limitation of emissions of certain pollutants into the air from large combustion plants. OJ L 309. 27.11.2001. Pp. 1-27.

4. Directive 2010/75/EU of the European Parliament and of the Council of 24 November 2010 on industrial emissions (integrated pollution prevention and control). OJ L 334/17. 17.12.2010. Pp. 17-119.

5. Directive (EU) 2015/2193 of the European Parliament and of the Council of 25 November 2015 on the limitation of emissions of certain pollutants into the air from medium combustion plants. OJ L 313, 28.11.2015. Pp. 1-19. 
6. The energy community legal framework. 4th Edition. Edited by Dirk Buschle and Heli Annika Lesjak. IMPRINT. Energy Community Secretariat. Vienna. 2018. 820 p.

7. Нормативи гранично допустимих викидів забруднюючих речовин із стаціонарних джерел. Міністерство охорони навколишнього природного середовища України, наказ 27.06.2006 № 309. Міністерство юстиції України, 1 серпня 2006 p. № $912 / 12786$. URL:

https://zakon.rada.gov.ua/laws/show/ru/z0912-06 (Дата звернення: 28.03.2019).

8. Жовмир Н.M. Анализ нормативных требований к эмиссии загрязняющих веществ при сжигании биомассы. Промышленная теплотехника. 2012. т.34. № 1. С. 77-86.

9. Directive 2018/2001/EC of the European Parliament and of the Council of 11 December 2018 on the promotion of the use of energy from renewable sources (recast). OJ L 328. 21.12.2018. Pp. 28-209.

10. Directive 2008/98/EC of the European Parliament and of the Council of 19 November 2008 on waste and repealing certain Directives (Text with EEA relevance). OJ L 312, 22.11.2008. (Edition 5.07.2018). Pp. 1 - 41.

11. Directive 2000/76/EC of the European Parliament and of the Council of 4 December 2000 on the incineration of waste. OJ L 332. 28.12.2000. Pp. 91-111 (with corrections 2000 L0076 EN. 11.12.2008-001.001. Pp. 1-31.

12. Decision of the Ministerial Council of the Energy Community of 24 October 2013 D/2013/05/MC-EnC: On the implementation of Directive 2001/80/EC of the European Parliament and of the Council of 23 October 2001 on the limitation of emissions of certain pollutants into the air from large combustion plants. $4 \mathrm{p}$.

13. Про затвердження технологічних нормативів допустимих викидів забруднюючих речовин із теплосилових установок, номінальна теплова потужність яких перевищуе 50 МВт. Міністерство охорони навколишнього природного середовища України. Наказ № 541 від 22 жовтня 2008 р. Міністерство юстиції України 17 листопада 2008p. № 1110/15801 (із змінами, внесеними наказами № 337 від 17.09.2015, № 62 від 16.02.2018). URL: https://zakon rada.gov.ua/laws/show/z1110-08 (Дата звернення: 28.03.2019).

14. Розпорядження Кабінету Міністрів України від 8 листопада 2017 р. № 796-р Про Національний план скорочення викидів від великих спалювальних установок. URL: https://zakon.rada.gov.ua/laws/show/796-2017-p (Дата звернення: 28.03.2019).

15. Технологічні нормативи допустимих викидів забруднюючих речовин у атмосферне повітря із котелень, що працюють на лушпинні соняшнику. Міністерство охорони навколишнього природного середовища України, наказ 13.10.2009 №540. Міністерство юстиції України 4 листопада 2009 p. № 1023/17039 (із змінами, внесеними наказом № 23 від 22.01.2016). URL: https://zakon.rada.gov.ua/laws/ show/z1023-09 (Дата звернення: 28.03.2019).

16. Межгосударственный стандарт ГОСТ 28269-89. Котлы паровые стационарные большой мощности. Общие технические условия. М. Стандартинформ. 2006. 23 с.

17. Volchyn I. Development of Non-Waste Production Technologies to Clean the Flue Gas from Pollutants. First Ukrainian-Polish Workshop "Improving the efficiency and environmental performance of processes of combustion, gasification and thermochemical conversion of solid fuels". Kyiv. 2017. 13 p.

18. ГОСТ 24005-80. Котлы паровые стационарные с естественной циркуляцией. Общие технические требования. Комитет по стандартизации и метрологии СССР. М. Изд-во стандартов, $1992.15 \mathrm{c}$.

19. Межгосударственный стандарт ГОСТ 28193-89. Котлы паровые стационарные с естественной циркуляцией паропроизводительностью менее 4 т/ч. Общие технические требования. М. Стандартинформ. 2007. 8 с.

20. Межгосударственный стандарт ГОСТ 21563-93. Котлы водогрейные. Основные параметры и технические требования. Межгосударственный совет по стандартизации, метрологии и сертификации. Минск. М. Издательство стандартов. 2003. 6 c.

21. Межгосударственный стандарт ГОСТ 30735-2001. Котлы отопительные водогрейные теплопроизводительностью от 0,10 до 4,0 МВт. Общие технические условия. Межгосударственный совет по стандартизации, метрологии и сертификации, Минск. М.: Издательство стандартов. 2002. 19 с.

22. Межгосударственный стандарт ГОСТ 20548-87. Котлы отопительные водогрейные теплопроизводительностью до 100 кВт. Общие технические условия. М. Издательство стандартов. 2002. 9 с. (В Україні введений як ДСТУ 2396-93).

23. Щодо надання роз'яснень у сфері охорони атмосферного повітря. Лист Міністерства екології та природних ресурсів України директору ТOB «ЕКО». URL: http://ecosoft.in.ua/norm_baza_vozdyx.html (Дата звернення: 28.03.2019).

24. Межгосударственный стандарт ГОСТ 33016-2014 (EN 303-5:2012, MOD). Котлы отопительные для твердого топлива с ручной и автоматической загрузкой номинальной тепловой мощностью до 500 кВт. Терминология, требования, методы испытаний и маркировка. Межгосударственный совет по стандартизации, метрологии и сертификации. М. Стандартинформ, 2015. $53 \mathrm{c}$.

\section{REFERENCES}

1. WHO air quality guidelines for particulate matter, ozone, nitrogen dioxide and sulfur dioxide. Global update 2005. Summary of risk assessment. World Health Organization. Geneva. 2006. 22 p. Retriver from

http://www.who.int/airpollution/publications [in English].

2. Aerosols from biomass combustion. Nussbaumer Th (Ed.). Zurich. 2001. 107 p. Retriver from verenum@access.ch [in English].

3. Directive 2001/80/EC of the European Parliament and of the Council of 23 October 2001 on the limitation of emissions of certain pollutants into the air from large combustion plants.

OJ L 309. 27.11.2001. Pp. 1-27. [in English].

4. Directive 2010/75/EU of the European Parliament and of the Council of 24 November 2010 on industrial emissions (integrated pollution prevention and control). OJ L 334/17. 17.12.2010. Pp. 17-119. [in English].

5. Directive (EU) $2015 / 2193$ of the European Parliament and of the Council of 25 November 2015 on the limitation of emissions of certain pollutants into the air from medium combustion plants. OJ L 313. 28.11.2015. Pp. 1-19. [in English].

6. The energy community legal framework. 4th Edition. Edited by Dirk Buschle and Heli Annika Lesjak. IMPRINT. Energy Community Secretariat. Vienna. 2018. 820 p. [in English].

7. Normatyvy hranychnodopustymykh vykydiv zabrudyuyuchykh rechvyn iz statsionarnykh dzherel. Ministerstvo ohorony navkolyshnoho pryrodnoho seredovyshcha Ukrainy. Nakaz 27.06.2006. No. 309. Ministerstvo yustytsii Ukrainy 1.08.2006. No. 912/12786. [Limits of pollutant emissions from stationary sources. Ministry of environment protection of Ukraine, Order 27.06.2006. No. 309. Ministry of justice of Ukraine 1.08.2006. No. 912/12786.] Retrieved from

https://zakon.rada.gov.ua/laws/show/ru/z0912-06 [In Ukrainian].

8. Zhovmir N.M. Analiz normativnykh trebovanij k emissii zagriazniayushchikh veshchestv pri szhiganii biomassy [Analysis of the regulatory requirements for pollutants emissions 
at biomass combustion]. Promyshliennaia teplotekhnika. 2012. v.34. No.1. Pp. 77-86. [In Russian].

9. Directive 2018/2001/EC of the European Parliament and of the Council of 11 December 2018 on the promotion of the use of energy from renewable sources (recast). OJ L 328. 21.12.2018. Pp. 28-209. [in English].

10. Directive 2008/98/EC of the European Parliament and of the Council of 19 November 2008 on waste and repealing certain Directives (Text with EEA relevance). OJ L 312 22.11.2008. (Edition 5.07.2018). Pp. 1-41. [in English].

11. Directive 2000/76/EC of the European Parliament and of the Council of 4 December 2000 on the incineration of waste. OJ L 332. 28.12.2000. Pp. 91-111 (with corrections 2000 L0076EN. 11.12.2008. 001.001. Pp. 1-31). [in English].

12. Decision of the Ministerial Council of the Energy Community of 24 October 2013 D/2013/05/MC-EnC: On the implementation of Directive 2001/80/EC of the European Parliament and of the Council of 23 October 2001 on the limitation of emissions of certain pollutants into the air from large combustion plants. 4 p. [in English].

13. Pro zatverdzhenniaia technolohichnykh normatyviv dopustymykh vykydiv zabrudniuiuchykh rechovyn iz teplosylovykh ustanovok, nominalna teplova potuzhnist yakykh perevyshchuye $50 \mathrm{MW}$. [On approval of the technological limits of permissible pollutants emissions from thermal plants having rated thermal input above $50 \mathrm{MW}$ ]. Ministry of environment protection of Ukraine. order 22.10.2008 No. 541. Ministry of justice of Ukraine 17.11.2008. No. 1110/15801 (with changes introduced by orders 17.09.2015 No. 337. 16.02.2018 No. 62). Retrieved from https://zakon.rada.gov.ua/laws/show/z1110-08 (Applying date: 28.03.2019). [In Ukrainian].

14. Rozporiadzhennia Kabinetu Ministriv Ukrainy 8.11.2017 No. 796-r. Pro Nastionalnyi plan skorochennia vykydiv vid velykykh spaliuvalnykh ustanovok. [About the National plan on emissions reduction from large combustion plants. Resolution of the Cabinet of Ministers of Ukraine 8.11.2017 No. 796r.]. Retrieved from https://zakon.rada.gov.ua/laws/show/7962017-r (Applying date: 28.03.2019). [In Ukrainian].

15. Tehnolohichni normatyvy dopustymykh vykydiv zabrudniuiuchykh rechovyn $\mathrm{u}$ atmosferne povitria iz kotelen, shcho pratsuiun na lushpynni soniashnyku. [Technological norms of permissible pollutants emissions into the atmospheric air from boilers burning sunflower husks]. Ministry of environment protection of Ukraine. order 13.10.2009 No. 540. Ministry of justice of Ukraine 4.11.2009. No. 1023/17039 (with changes introduced by order 22.01.2016 No. 23). Retrieved from https://zakon.rada.gov.ua/laws/show/z1023-09 (Applying date: 28.03.2019). [In Ukrainian].

16. Mezhgosudarstvennyi standart GOST 28269-89. Kotly parovyie statsionarnyie bolshoi moshchnosti. Obshchiie tehnicheskiie usloviia. [Interstate standard GOST 28269-89. Stationary steam boilers of great capacity. General technical requirements]. M. Standartinform. 2006. 23 p. [In Russian].

17. Volchyn I. Development of Non-Waste Production Technologies to Clean the Flue Gas from Pollutants. Presentation at the First Ukrainian-Polish Workshop "Improving the efficiency and environmental performance of processes of combustion, gasification and thermochemical conversion of solid fuels". Kyiv. 2017. 13 p. [in English].

18. GOST 24005-80. Kotly parovyie statsionarnyie s estestvennoi tsirkuliatsiiei. Obshchiie tehnicheskiie trebovaniia Komitet po metrologii i standartizatsii SSSR. [GOST 24005-80. Natural circulation stationary steam boilers. General technical requirements. Metrology and standardization Committee]. M. Izdatelstvo standartov. 1992. 15 p. [In Russian].

19. Mezhgosudarstvennyi standart GOST 28193-89. Kotly parovyie statsionarnyie $\mathrm{s}$ estestvennoi tsirkuliatsiiei paroproizvoditelnostiiu mienieie 4 t/chas. [Interstate standard GOST 28193-
89. Natural circulation stationary steam boilers less than $4 \mathrm{t} / \mathrm{h}$. General requirements]. M. Standartinform. 2007. 8 p. [In Russian].

20. Mezhgosudarstvennyi standart GOST 21563-93. Kotly vodogrieinyie. Osnovnyie parametry i technicheskiie trebovaniia. Mezhgosudarstvennyi sovet po standartizatsii, metrologii i sertifikatsii, Minsk. [Interstate standard GOST 21563-93. Hotwater boilers. Main parameters and technical requirements. Interstate standardization, metrology, and certification committee, Minsk]. M. Izdatelstvo standartov. 2003. 6 p. [In Russian].

21. Mezhgosudarstvennyi standart GOST 30735-2001. Kotly otopitelnyie vodogreinyie teploproizvoditelnostiu ot 0.10 do 4.0 MW. Obshchiie technicheskiie usloviia. Mezhgosudarstvennyi sovet po standartizatsii, metrologii i sertifikatsii, Minsk. [Interstate standard GOST 30735-2001. Heating hot water boilers with capacity from 0.1 to $4.0 \mathrm{MW}$. General specifications. Interstate council on standardization, metrology, and certification, Minsk]. M. Izdatelstvo standartov. 2002. 19 p. [In Russian].

22. Mezhgosudarstvennyi standart GOST 20548-87. Kotly otopitelnyie vodogreinyie teploproizvoditelnostiu do $100 \mathrm{~kW}$. Obshchiie technicheskiie usloviia. [Interstate standard GOST 20548-87. Heating hot-water boilers with capacity to $100 \mathrm{~kW}$. General specifications]. M. Izdatelstvo standartov. 2002. 9 p. (In Ukraine introduced as DSTU 2396-93). [In Russian].

23. Shchodo nadannia roziasnen u sferi ohorony atmosfernoho povitria. Lyst Ministerstva ekolohii ta pryrodnykh resursiv Ukrainy dyrectoru TOV "EKO" [About clarification on atmospheric air protection. Letter of Ministry of ecology and natural resources of Ukraine to director of "EKO" ltd.] Retrieved from http://ecosoft.in.ua/norm_baza_vozdyx.html (Applying date: 28.03.2019). [In Ukrainian].

24. Mezhgosudarstvennyi standart GOST 33016-2014 (EN 303-5:2012, MOD). Kotly otopitelnyie dlia tverdogo topliva s ruchnoi i avtomaticheskoi zagruzkoi nominalnoi teplovoi moshchnostiu do $500 \mathrm{~kW}$. Terminologiia, trebovaniia, metody ispytanii i markirovka. Mezhgosudarstvennyi sovet po standartizatsii, metrologii i sertifikatsii. [Interstate standard GOST 33016-2014 (EN 303-5:2012, MOD).Heating boilers for solid fuels, manually and automatically stoked, nominal heat output of up to $500 \mathrm{~kW}$. Terminology, requirements, test methods and marking. Interstate council on standardization, metrology, and certification]. M. Standartinform. 2015. 53 p. [In Russian]

\section{ОСОБЕННОСТИ ПРИМЕНЕНИЯ НОРМАТИВНЫХ ДОКУМЕНТОВ ОБ ОГРАНИЧЕНИИ ЭМИССИИ ЗАГРЯЗНЯЮЩИХ ВЕЩЕСТВ ПРИ СЖИГАНИИ БИОМАССЫ}

Н.М. Жовмир ${ }^{1}$, канд. техн. наук, М.А. Будько ${ }^{2}$ канд. техн. наук

${ }^{1}$ Институт возобновляемой энергетики НАН Украины 02094, ул. Гната Хоткевича, 20A, г. Киев, Украина ${ }^{2}$ Национальный технический университет Украины «Киевский политехнический институт им. И. Сикорского» 03056, проспект Победы 37, г. Киев, Украина

Цель работь - выяснить влияние изменений в нормативных документах о зашите атмосферного воздуха от загрязнения на дальнейшую эксплуатацию существуюших и внедрение новых энергетических установок, разработку новых процессов и котельного оборудования для сжигания биомассы. Представлено анализ изменений существующих международных документов, стандартов и нормативных актов Украины, касаюшчихся ограничения выбросов загрязняющих веществ от энергетических установок со сжиганием биомассы.

Переизданной директивой ЕС установлень экологические требования для больших сжигаюших установок (более $50 \mathrm{MBm}$ ) которые дифференциированы в зависимости от их 
мочности по топливу и введены в действие для новых установок с 2018 г, а для существуюших внедряются в два этапа - с 2014 г. и 2028 г. Нормативными документами Украины для больших сжигающих установок запланирован постепенный переход на нормативы ЕС до 20332. Учитывая особенности введения современных экологических требований, совместное сжигание биомассы и угля на существуюших больших электрических станциях Украины может стать реальным с приближением периода 2028 - 2033 годов.

В 2015 году ЕС принял экологические нормативы для средних сжигаюших установок (1-50 MBm), которые для новых установок вводятся с 2018 г., а для существуюших установок мощностью более $5 \mathrm{MBm}$ вводятся с 2025 г., а для установок мощцостью 1-5 MBm - с 2030 г. Для средних сжигаюших установок в Украине приняты технологические экологические нормативы только для сжигания лузги под- солнечника, а для сжигания других твердых топлив действуют экологические нормативы общие для всех стационарных источников загрязнения. При планировании реконструкции и продлении эксплуатации сущуествующих средних энергетических установок со сжиганием лузги подсолнечника можно ориентироваться на перспективные технологические нормативы, действуюшие в Украине.

В Украине граничнодопустимые выбросы твердых частич обшие для всех стационарных источников загрязнения со сжиганием твердого топлива являются более низкими, чем требования стандарта EN 303-5:2012 к отопительным котлам (до 500 кВт) третьего класса, особенно при сжигании торфа и соломь, поэтому есть необходимость разработки первичных мероприятий для уменьшения их эмиссии до общих требований. Библ.24, табл.11.

Ключевые слова: сжигаюшая установка, котел, биомасса, сжигание, загрязняющие вещества, эмиссия, ограничение.

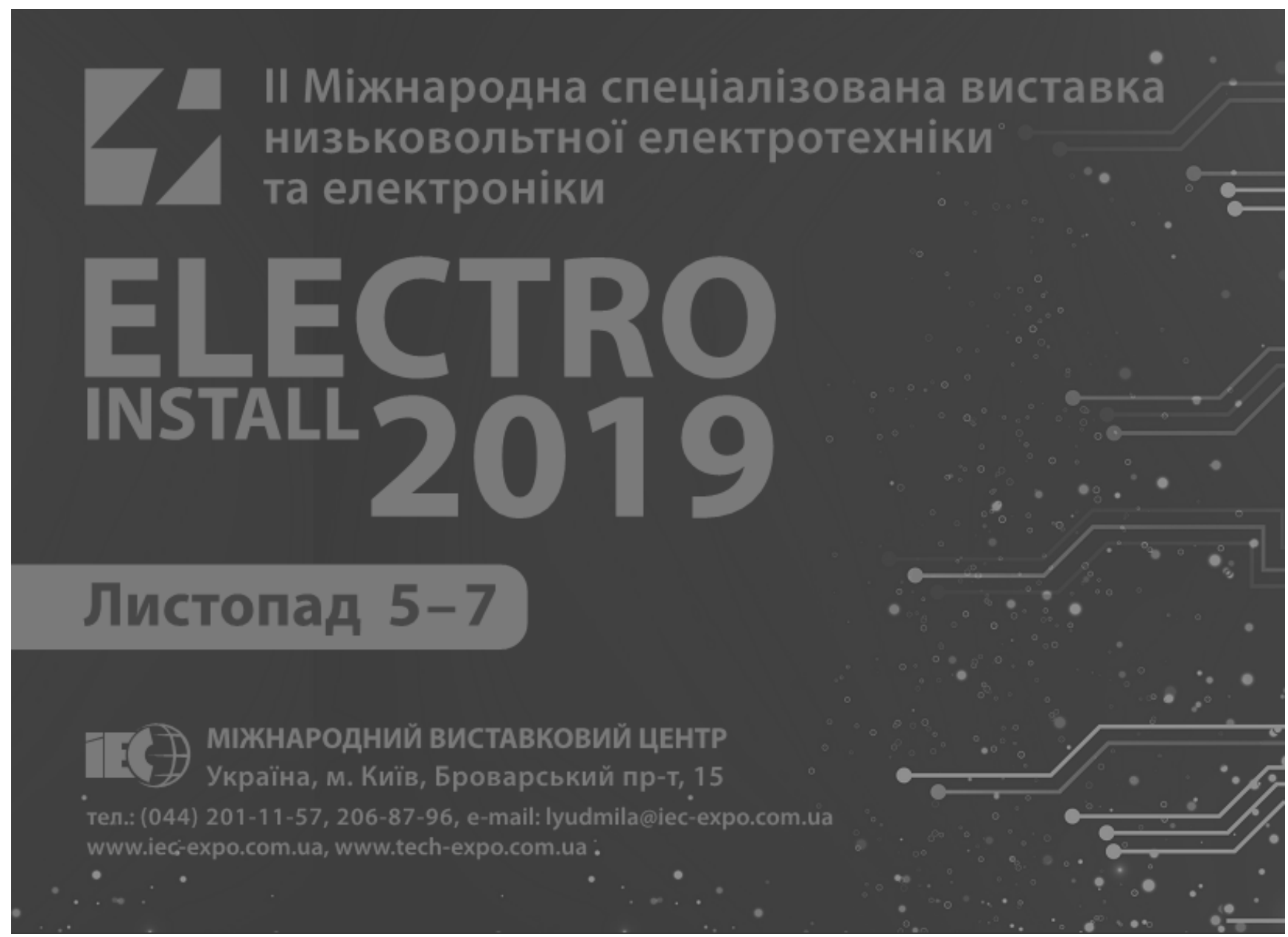

